\title{
Adequacy Of Urban Mass Transit Bus System And Commuters' Modal Choice In Abuja
}

\author{
Chika O. Nwankwo \\ Centre for Logistics and Transport Studies, University of Port Harcourt, Port Harcourt Nigeria, \\ chikacpcd@gmail.com
}

M. Frank Baridoma

| Centre for Logistics and Transport Studies, University of Port Harcourt, Port Harcourt Nigeria,

chikacpcd@gmail.com

\begin{tabular}{|c|c|}
\hline & ABSTRACT \\
\hline $\begin{array}{l}\text { Keywords: } \\
\text { Transport, } \\
\text { Vehicle, } \\
\text { Commuter, } \\
\text { Passenger, } \\
\text { Modal, Choice }\end{array}$ & $\begin{array}{l}\text { The study investigated adequacy of urban mass transit bus system and passenger modal choice in Abuja. The study } \\
\text { focused on the adequacy of Terminals, Bus stops and functionality of the system from the Commuters and Operators } \\
\text { perception. } 399 \text { Commuters were sampled through a Simple random sampling technique. Data were sourced through } \\
\text { primary sources using questionnaires for Commuters and interview for Urban Mass Transit Bus (UMTB) Operators. } \\
\text { Data were analyzed using tables, percentages and charts while Hypotheses were tested using one-way ANOVA. From } \\
\text { the findings, } 84.0 \% \text { of Commuters indicated that UMTB functionality was highly inadequate. } 64.3 \% \text { of the Commuters } \\
\text { were of the opinion that the Bus stops were inadequate, } 66.9 \% \text { of the Commuters were of the opinion that the } \\
\text { Terminals were inadequate. All the licensed UMTB Operators agreed that the system functionality is inadequate. As a } \\
\text { result, majority of the Commuters would prefer to board private cars rather than UMTB. The study recommends } \\
\text { provision of adequate Bus stops, Terminals, dedicated Bus Rapid Transit (BRT) lane and ensure Operational coherency } \\
\text { in the study areas. }\end{array}$ \\
\hline
\end{tabular}




\section{Introduction}

Modern public transportation systems in many places of the world are moving towards integrating best practices [15], that are efficient, effective, reliable, sustainable, safe, comfortable, convenient, adequate, timely and cost-affordable [13].

A well patronized public (urban) transport system is critically dependent on how effective the system is operated and managed. To this effect, public transportation modes require service quality improvements. For any meaningful improvements in public transportation to be made, evaluation of utility standard of available public transport like urban mass transit bus system by general communal insight is necessary [11].

Public transportation is a system of moving passengers or freight with private or public carriers for a financial reward [14]. Bus, rail, light rail, tramways, monorails, and water transportation make up a Public transport system. Passengers' preference of one or more of the modes of public transport depends on area characteristics. One of the main characteristics of high occupancy bus transport system is that it is one of the cheapest and affordable transport systems. The urban mass transit bus scheme is a public transport arrangement involving mainly high occupancy buses with larger passenger space, operating on defined road with predetermined timetable or adjustably routed [9]. [6], characterized the four physical essentials of transport as; The Way; The Terminus; The Carrying Unit and The Motive power. These must be adequate for any public transport system to function effectively.

Despite the crucial role of urban mass transit bus system in the sustainable development of any society, their services in Nigerian cities like Abuja are inefficient in meeting the increasing demand of transport services by Abuja residents. Passengers are not satisfied with the functionality of public bus transport services in Abuja [3]. Bus stops are not adequate, the buses are not easily seen and the few available ones are over-crowded, thereby leading to poor services rendered [8]. This situation many times cause Passengers to board private cars for movement in which the drivers are either known or unknown to them thereby making the private cars illegal passenger service vehicles. In the light of the above, this study is aimed at investigating the adequacy of urban mass transit bus and Commuters' modal choice in Abuja.

\subsection{Research Hypotheses}

I. $\mathrm{H}_{0}$ : There is no statistically significant difference in the volume of Commuters that board private cars and those that board urban mass transit buses.

$\mathrm{H}_{1}$ : There is statistically significant difference in the volume of Commuters that board private cars and those that board urban mass transit buses.

II. $\mathrm{H}_{0}$ : There is no statistically significant difference in the factors that influence Commuters choice of boarding mass transit buses and boarding private cars.

$\mathrm{H}_{1}$ : There is statistically significant difference in the factors that influence Commuters choice of boarding mass transit buses and boarding private cars. 


\section{Literature Review}

[7], assessed Passenger satisfaction with Intra-City Public Bus Transport Services in Abuja. Findings revealed that passengers were not satisfied with the public bus transport services in Abuja. [9], evaluated urban mass transit systems and its problems of equitable bus service distribution to the masses in Abuja, Nigeria. The result of the findings showed that the current efficiency of the organized bus transit operators in Abuja is poor. [2], appraised the spatial location of bus-stops in Ilorin metropolis. The research revealed that most of the existing designated and improvised bus-stops were found to be clustered together around the commercial land uses. More improvised bus-stops were found than the designated ones which may be because many of the improvised bus stops emerged naturally as need arises and that bus-stop designation was not scientifically done in the first place. [12], used GIS application in determining public transport access level in Abuja, Nigeria. Findings revealed that access to public transport in FCT was inadequate. [4], examined road infrastructure development in Nigeria. The focus was to analyze the impact of road infrastructural development on some selected corridors in Abuja metropolis. The study showed that after the roads expansion in Abuja, there was reduction in the total average travel time from 138.3 minutes in 2010 to 63.3 minutes in 2013 in the three selected corridors. [8], studied Abuja Urban Mass Transport Company (AUMTCO) operations impact on Passengers' movement in Abuja. Results showed that commuters rated them very low. It also revealed that both the bus stops, the Buses and their services were inadequate. It can be noted that issues that relates to urban mass transit bus system and Passengers' modal choice problems are yet to be covered by researchers. Therefore, the objective of this study is hinged on the adequacy of the Urban Mass Transit Bus (UMTB) system (based on Passengers' and Operators' perception) and factors that influence Passengers' modal choice.

\section{Material and Method}

\subsection{The Study Area}

Lagos as the capital of Nigeria had a lot challenges that do not befit the capital of a nation like Nigeria. As a result, the Federal Capital Territory, Abuja was created by decree No. 6 of February $4^{\text {th }}, 1976$ [1]. Abuja is centrally located in Nigeria. It covers a total of 8,000 square Kilometres of land. It is geographically situated on latitude $8^{\circ}$ $25^{\prime \prime}$ and $9^{\circ} 25^{\prime \prime}$ North of the Equator and Longitude $6^{\circ} 45^{\prime \prime}$ and $7^{\circ} 45^{\prime \prime}$ East of the Greenwich. Due to better infrastructural development, Transportation in Abuja is better than many cities in Nigeria [10]. There are three main transportation corridors leading in and out of the federal capital city. These transport corridors are; Musa Yar'dua Expressway, Murtala Muhammed Expressway and Abuja-Keffi expressway. Air transportation is facilitated by the Nnamdi Azikiwe International Airport. There is a standard gauge rail line from Abuja to Kaduna. 


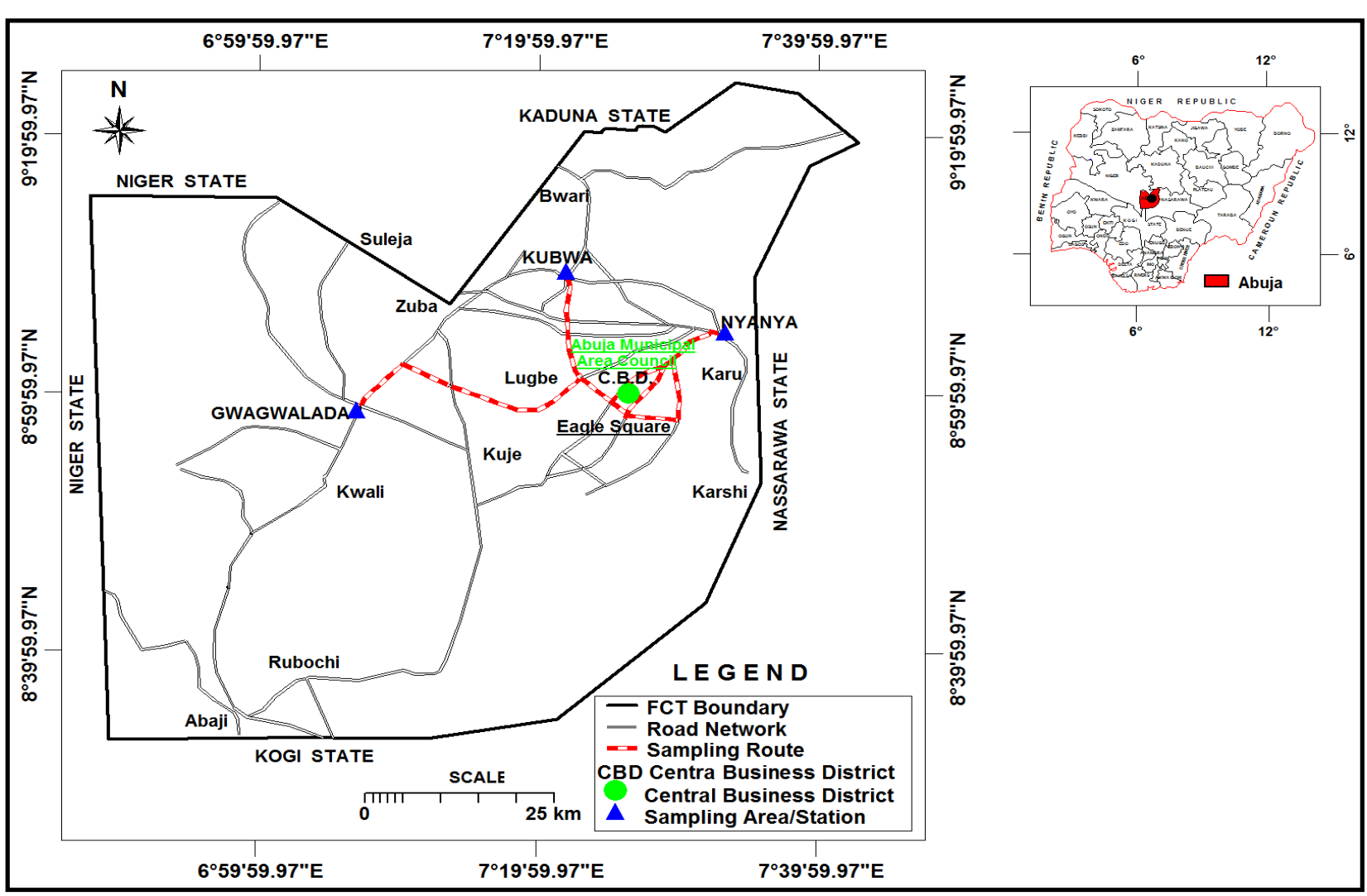

Source: Administrative Map of Federal Capital Territory, Abuja (2015)

Figure 1. Map of Federal Capital Territory, Abuja

\subsection{Presentation of Data}

The study made use of primary data collected from Commuters and licensed UMTB Operators using questionnaire for Commuters and interview for the Operators. The objective was to assess the adequacy of Terminals, Bus stops and functionality of the UMTB system based on Commuters and Operators perception and also to determine factors that influence Commuters modal choice in the study area. Data collected were analysed and presented using percentages and tables. Hypothesis were tested using one-way ANOVA.

\subsubsection{Sample Size determination}

The Taro Yamane's formula. The formula is designed thus:

$$
n=\frac{N}{1+N(e)^{2}}
$$

Where: $\mathrm{n}=$ Sample size

$\mathrm{N}=$ Population

e $=$ Level of precision or sampling error at 0.05 at $95 \%$ confidence level.

Using the population figures for each municipal area; Gwagalada $=158,618$; Kubwa= 229,274; and Nyanya=776,298. A total of 1164,190 was obtained and this was subjected to Taro Yamane formula to obtain a sample size for the study. 
Thus;

$\begin{array}{lc}\mathrm{n}=\frac{1,164,190}{1+1,164,190(0.05)^{2}} & \mathrm{n}=\frac{1,164,190}{1+1,164,190(0.0025)} \\ \mathrm{n}=\frac{1,164,190}{1+2911.474} & \mathrm{n}=\frac{1,164,190}{2911.475} \\ \mathrm{n}=399 \text { (sample size) } & \end{array}$

In choosing a number from the strata, the study ensured that the number of commuters selected from a particular stratum was proportional to the stratum's share of the total population. This was achieved by the proportional distribution of the sample size of 399 among the areas. Thus, since Nyanya (AMAC) had the highest population, sample was given as 150, while Gwagwalada (Gwagwalada Area Council) and Kubwa (Bwari Area Council) shared 125 and 124sample sizes.

\subsubsection{Respondents Public Transport Route}

Table 1. Respondents Public Transport Route

\begin{tabular}{|l|l|l|l|l|}
\hline \multirow{2}{*}{ Response } & \multicolumn{3}{l|}{ Transport Routes } & Total \\
\cline { 2 - 5 } & Gwagwalada & Kubwa & Nyanya & \\
\hline \multirow{2}{*}{ I usually move from } & 98 & 93 & 126 & 317 \\
\cline { 2 - 5 } & $82.4 \%$ & $76.9 \%$ & $89.4 \%$ & $83.2 \%$ \\
\hline \multirow{2}{*}{ I don't move from } & 21 & 28 & 15 & 64 \\
\cline { 2 - 5 } & $17.6 \%$ & $23.1 \%$ & $10.6 \%$ & $16.8 \%$ \\
\hline \multirow{2}{*}{ Total } & 119 & 121 & 141 & 381 \\
\hline & $100.0 \%$ & $100.0 \%$ & $100.0 \%$ & $100.0 \%$ \\
\hline
\end{tabular}

Source: Researcher's Fieldwork, 2017

Table 1. showed the results for the respondents' route. Distribution showed respondents (82.4\%) usually move from Gwagwalada route, $76.9 \%$ of the respondents move from Kubwa route, while $89.4 \%$ of the respondents move from Nyanya route. The distribution showed that all the respondents move from any of the selected transport route but location was the determining factor influencing where they move from.

\subsubsection{Assessment of the Adequacy of Urban Mass Transit among Commuters, and Operators}

Table 2. Transport Mode used among Commuters

\begin{tabular}{|l|l|l|l|l|}
\hline \multirow{2}{*}{ Transport Mode } & Transport Routes & & \\
\cline { 2 - 3 } & Gwagwalada & Kubwa & Nyanya & Total \\
\hline \multirow{2}{*}{ Private car } & 55 & 38 & 71 & 164 \\
\hline \multirow{2}{*}{ Abuja urban mass transit bus } & $46.2 \%$ & $31.4 \%$ & $50.4 \%$ & $43.0 \%$ \\
\hline \multirow{2}{*}{ Mini bus } & 36 & 34 & 43 & 113 \\
\hline \multirow{2}{*}{ Others } & $30.3 \%$ & $28.1 \%$ & $30.5 \%$ & $29.7 \%$ \\
\hline \multirow{2}{*}{ Total } & 12 & 17 & 14 & 43 \\
\hline & $10.1 \%$ & $14.0 \%$ & $9.9 \%$ & $11.3 \%$ \\
\hline
\end{tabular}

Source: Researcher's Fieldwork, 2017 
Table 2. showed the distribution for the type of transport mode used among commuters. Findings showed respondents (43\%) board private cars, $29.7 \%$ of the respondents uses the Abuja urban mass transit, $11.3 \%$ of the respondents utilizes the Mini buses, while $16 \%$ of the remaining respondents uses other means ranging from taxis to shuttle vans. The study therefore concludes that the Abuja urban mass transit bus is not well utilized among Commuters of the public transport system.

Table 3. Level of Adequacy of the Bus Terminals among Commuters

\begin{tabular}{|l|l|l|l|l|}
\hline \multirow{2}{*}{ Transport Mode } & Transport Routes & \multirow{2}{*}{ Total } \\
\cline { 2 - 5 } Adequate & Gwagwalada & Kubwa & Nyanya & \\
\hline \multirow{2}{*}{ Inadequate } & 38 & 34 & 31 & 103 \\
\cline { 2 - 5 } & $31.9 \%$ & $28.1 \%$ & $22.0 \%$ & $27.0 \%$ \\
\hline \multirow{2}{*}{ Others } & 74 & 76 & 105 & 255 \\
\cline { 2 - 5 } & $62.2 \%$ & $62.8 \%$ & $74.5 \%$ & $66.9 \%$ \\
\hline \multirow{2}{*}{ Total } & 7 & 11 & 5 & 23 \\
\hline & $5.9 \%$ & $9.1 \%$ & $3.5 \%$ & $6.1 \%$ \\
\hline & 119 & 121 & 141 & 381 \\
\hline
\end{tabular}

Source: Researcher's Fieldwork, 2017

Table 3. showed the results for the level of adequacy of bus terminals. Distribution showed that $27 \%$ of the respondents believed it was adequate, $66.9 \%$ of the respondents were of the opinion that it was not adequate, while the remaining $6.1 \%$ of the respondents believed it to be fair. However, the study concluded that the urban mass transit bus terminals in Abuja were not adequate as perceived by majority of sampled commuters in the study area.

Table 4. Adequacy of the Bus stops along Transport Routes among Commuters

\begin{tabular}{|l|l|l|l|l|}
\hline \multirow{2}{*}{ Transport Mode } & \multicolumn{3}{l|}{ Transport Routes } & \multirow{2}{*}{ Total } \\
\cline { 2 - 4 } Adequate & Gwagwalada & Kubwa & Nyanya & \\
\hline \multirow{3}{*}{ Inadequate } & 51 & 31 & 31 & 113 \\
\cline { 2 - 4 } & $42.9 \%$ & $25.6 \%$ & $22.0 \%$ & $29.7 \%$ \\
\hline \multirow{2}{*}{ Others } & 58 & 81 & 106 & 245 \\
\hline \multirow{2}{*}{ Total } & $10.7 \%$ & $66.9 \%$ & $75.2 \%$ & $64.3 \%$ \\
\cline { 2 - 5 } & $8.4 \%$ & 9 & 4 & 23 \\
\hline
\end{tabular}

Source: Researcher's Fieldwork, 2017

Table 4. presented information concerning the level of adequacy of the UMTB. Results showed that $29.7 \%$ of commuters were pleased with the bus stops along traffic routes, $64.3 \%$ of the respondents are not satisfied, while the remaining $6 \%$ of the respondents have indifferent about choices to make. However, the study concluded that the bus stops along transport routes in the study area are not adequate as perceived by majority of sampled respondents for the study.

Table 5. Functionality of the Urban Mass Transit System among Commuters

\begin{tabular}{|l|l|l|l|l|}
\hline \multirow{2}{*}{ Transport Mode } & \multicolumn{2}{|l|}{ Transport Routes } & \multirow{2}{*}{ Total } \\
\cline { 2 - 5 } & Gwagwalada & Kubwa & Nyanya & \\
\hline \multirow{2}{*}{ Yes Adequate and Functional } & 10 & 12 & 25 & 47 \\
\cline { 2 - 5 } & $8.4 \%$ & $9.9 \%$ & $17.7 \%$ & $12.3 \%$ \\
\hline Not adequate and non-functional & 104 & 103 & 113 & 320 \\
\cline { 2 - 5 } & $87.4 \%$ & $85.1 \%$ & $80.1 \%$ & $84.0 \%$ \\
\hline \multirow{2}{*}{ Others } & 5 & 6 & 3 & 14 \\
\hline \multirow{2}{*}{ Total } & $4.2 \%$ & $5.0 \%$ & $2.1 \%$ & $3.7 \%$ \\
\hline
\end{tabular}


Table 5. presented information concerning the level of UMTB functionality. The distribution showed that $12.3 \%$ of the respondents were of the opinion that it is functional, $84 \%$ of the respondents believed that it is not functional, while $3.7 \%$ of the remaining respondents were undecided about making a choice. From the results it shows that bulk of sampled Commuters agreed that the quantity of UMTB provided are not adequate and not functioning effectively. The study therefore concluded that the UMTB system is not adequate, with poor bus terminal and bus stops in the study area.

Table 6. Assessment of the Level of Adequacy of Urban Mass Transit among Operators

\begin{tabular}{|c|c|c|c|c|c|c|c|c|c|c|c|c|c|c|}
\hline \multirow{2}{*}{$\begin{array}{l}\mathbf{S} / \\
\mathbf{N}\end{array}$} & \multirow{2}{*}{$\begin{array}{l}\text { Operat } \\
\text { ors }\end{array}$} & \multicolumn{4}{|c|}{ Bus Terminals } & \multicolumn{4}{|c|}{ Bus Stops } & \multicolumn{5}{|c|}{ Functionality } \\
\hline & & $\begin{array}{l}\text { Very } \\
\text { Adequ } \\
\text { ate }\end{array}$ & $\begin{array}{l}\text { Adequ } \\
\text { ate }\end{array}$ & $\begin{array}{l}\text { Very } \\
\text { inadeq } \\
\text { uate }\end{array}$ & $\begin{array}{l}\text { Inadeq } \\
\text { uate }\end{array}$ & $\begin{array}{l}\text { Very } \\
\text { Adequ } \\
\text { ate }\end{array}$ & $\begin{array}{l}\text { Adequ } \\
\text { ate }\end{array}$ & $\begin{array}{l}\text { Very } \\
\text { inadeq } \\
\text { uate }\end{array}$ & $\begin{array}{l}\text { Inadeq } \\
\text { uate }\end{array}$ & $\begin{array}{l}\text { Excell } \\
\text { ent }\end{array}$ & $\begin{array}{l}\text { Ver } \\
\text { y } \\
\text { Go } \\
\text { od }\end{array}$ & $\begin{array}{l}\text { Go } \\
\text { od }\end{array}$ & $\begin{array}{l}\text { Belo } \\
\text { w } \\
\text { Avera } \\
\text { ge }\end{array}$ & $\begin{array}{l}\text { Po } \\
\text { or }\end{array}$ \\
\hline 1 & $\begin{array}{l}\text { AUMTC } \\
0\end{array}$ & & & & $x$ & & & $x$ & & & $x$ & & & \\
\hline 2 & $\begin{array}{l}\text { Autost } \\
\text { ar Nig. } \\
\text { Ltd. }\end{array}$ & & & & $x$ & & & $x$ & & & & & $x$ & \\
\hline 3 & NARTO & & & $x$ & & & & & $x$ & & & & & $x$ \\
\hline 4 & $\begin{array}{l}\text { NURT } \\
\text { W }\end{array}$ & & & $x$ & & & & $x$ & & & & & $x$ & \\
\hline 5 & RTEAN & & & $x$ & & & & $x$ & & & & & & $x$ \\
\hline 6 & RTEIN & & & $x$ & & & & $x$ & & & & & & $x$ \\
\hline 7 & $\begin{array}{l}\text { SECDA } \\
\text { A }\end{array}$ & & & $x$ & & & & & $x$ & & & & $x$ & \\
\hline 8 & $\begin{array}{l}\text { *Fabre } \\
\text { m Nig. } \\
\text { Ltd. }\end{array}$ & & & & & & & & & & & & & \\
\hline 9 & $\begin{array}{l}\text { *MTI } \\
\text { Bristol }\end{array}$ & & & & & & & & & & & & & \\
\hline 10 & $\begin{array}{l}{ }^{*} \text { TUC } \\
\text { Ltdd. }\end{array}$ & & & & & & & & & & & & & \\
\hline
\end{tabular}

Source: Researcher's Fieldwork, 2017

* No longer in Operation

AUMTCO- Abuja Urban Mass Transport Company; NARTO-National Association of Road Transport Owners (NARTO); NURTW-National Union of Road Transport Workers; RTEAN-Road Transport Employers Association of Nigeria; RTEIN-Road Transport Employers Initiative of Nigeria; SECDAA-Self Employed Commercial Drivers Association Limited, Abuja

Table 6. presented information concerning the level of adequacy as perceived by Operators. Responses varied among operators. AUMTCO believed that the bus terminals are inadequate; bus stops are very inadequate but ticked the functioning good. The Autostar UMTB Operator rated the bus terminals inadequate, the bus stops very inadequate and also believed that the urban mass transits as a whole have been poor in terms of the functionality. NARTO limited, believed that UMTB system has very inadequate bus terminals and bus stops, and poor functionality. These ratings were also repeated by RTEAN and RTEIN transport companies as regards the bus terminals, bus stops and function. However, the NURTW believed that the bus terminals and bus stops were very inadequate with functions that are below average. The SECDAA rated the urban mass transit the same way as the NURTW. 


\subsubsection{Choice of mode of travel among Commuters in the study area}

Table 7. Commuters' Modal choice

\begin{tabular}{|l|l|l|l|l|}
\hline \multirow{2}{*}{ Transport Mode } & \multicolumn{3}{|l|}{ Transport Routes } & \multirow{2}{*}{ Total } \\
\cline { 2 - 4 } & Gwagwalada & Kubwa & Nyanya & \\
\hline \multirow{2}{*}{ Private car } & 76 & 59 & 65 & 200 \\
\hline \multirow{2}{*}{ Urban mass transit (big) Bus } & $63.9 \%$ & $48.8 \%$ & $46.1 \%$ & $52.5 \%$ \\
\cline { 2 - 5 } & 28 & 42 & 54 & 124 \\
\hline \multirow{2}{*}{ Others } & $23.5 \%$ & $34.7 \%$ & $38.3 \%$ & $32.5 \%$ \\
\hline \multirow{2}{*}{ Total } & 15 & 20 & 22 & 57 \\
\hline & $12.6 \%$ & $16.5 \%$ & $15.6 \%$ & $15.0 \%$ \\
\hline
\end{tabular}

Source: Researcher's Fieldwork, 2017

Table 7. revealed Commuters' modal choice. The distribution revealed that $52.5 \%$ of the respondents preferred to board unknown private car for movement to work, $32.5 \%$ of the respondents preferred the UMTB, while the remaining $15 \%$ of the respondents preferred other forms of private vehicles like space wagon, shuttle and so on. Thus, the study concludes that majority of respondents prefer the use of private vehicles for travel or movement to place of work and for different purposes because of its speed and comfortability.

\subsubsection{Reasons for Commuters Modal Choice}

Table 8. Reasons for Choice of Transport Mode

\begin{tabular}{|l|l|l|}
\hline Reasons for Choice of Transport Mode & Frequency & Percentage (\%) \\
\hline Cost effective (Private Vehicles) & 71 & 18.6 \\
\hline Faster/Speed (Private Vehicles) & 78 & 20.5 \\
\hline Flexibility (Private Vehicles) & 64 & 16.8 \\
\hline Safety (UMTB) & 36 & 9.4 \\
\hline Low fare (UMTB) & 41 & 10.8 \\
\hline Comfortability (Private Vehicles) & 44 & 11.5 \\
\hline Comfortability (UMTB) & 53 & 13.9
\end{tabular}

Source: Researcher's Fieldwork, 2017

Table 8. showed the responses received in relation to the reasons for choice of vehicle among sampled commuters in the study area. The identified reasons among commuters who prefer using the private vehicles were cost effective $(18.6 \%)$, faster (20.5\%), flexibility (16.8\%), and comfortability (11.5\%); while those respondents that prefer using UMTB identified reasons like safety $(9.4 \%)$, low fare $(10.8 \%)$, and comfortability (10.8\%).

\subsection{Hypotheses Testing}

\subsubsection{Hypothesis 1:}

$\mathrm{H}_{0}$ : There is no statistically significant difference in the volume of Commuters that board private cars to those that board urban mass transit buses.

$\mathrm{H}_{1}$ : There is a statistically significant difference in the volume of commuters that board private cars to those that board urban mass transit.

Table 9. One way ANOVA Computed for Hypothesis 1

\begin{tabular}{|l|l|l|l|l|l|}
\hline & Sum of Squares & Df & Mean Square & F ratio & Significance at $p=0.05$ \\
\hline Between Groups & 3.281 & 2 & 1.640 & 3.100 & 0.046 \\
\hline Within Groups & 200.047 & 378 & 0.529 & & \\
\hline Total & 203.328 & 380 & & & \\
\hline
\end{tabular}

Source: Researcher's Analysis, 2017 
The result of the One Way ANOVA for hypothesis 1 was indicated on Table 9. The result showed that the $F$ ratio of 3.100 at $p=0.05$ was 0.046 . However, since the level of significance of 0.046 was lower than the $p$ value of 0.05 , thus we reject the null hypothesis $\left(\mathrm{H}_{0}\right)$ and accept the alternative $\mathrm{H}_{1}$. Therefore, there is a statistically significant difference in the volume of Commuters that board private cars to those that board urban mass transit buses in the study area.

\subsubsection{Hypothesis 2:}

$\mathrm{H}_{0}$ : There is no statistically significant difference in the factors that influence Commuters' choice of boarding private cars to urban mass transit buses.

$\mathrm{H}_{1}$ : There is a statistically significant difference in the factors that influence Commuters' choice of boarding private cars to urban mass transit buses.

Table 10. One way ANOVA Computed for Hypothesis 3

\begin{tabular}{|l|l|l|l|l|l|}
\hline & Sum of Squares & Df & Mean Square & F ratio & Significance at $\mathrm{p}=0.05$ \\
\hline Between Groups & 12.862 & 1 & 12.862 & 9.912 & 0.002 \\
\hline Within Groups & 986.173 & 760 & 1.298 & & \\
\hline Total & 999.035 & 761 & & & \\
\hline
\end{tabular}

Source: Researcher's Analysis, 2017

The stated hypothesis three was tested using the One way ANOVA and the result of the test was indicated on Table 10. The distribution showed that the $F$ ratio of 9.912 at $p=0.05$ was 0.002 . However, since the level of significance of 0.002 was lower than the $p$ value of 0.05 , thus we reject the null hypothesis $\left(\mathrm{H}_{0}\right)$ and accept the alternative $\mathrm{H}_{1}$. Therefore, there is a statistically significant difference in the factors that influence commuters' choice of boarding private cars to urban mass transit buses.

\section{Discussion}

Study findings revealed that the level of adequacy of the UMTB system among Commuters and Operators was inadequate with references to the bus terminals, bus stops and functionality which made the system performance to be poor and below average. Commuters' modal choice of UMTB were contingent upon safety, low fare and comfortability while for private car are cost effectiveness, faster/speed, comfortability and flexibility. From the findings, $84.0 \%$ of Commuters indicated that UMTB functionality was highly inadequate. $64.3 \%$ of the Commuters were of the opinion that the Bus stops were inadequate, $66.9 \%$ of the Commuters were of the opinion that the Terminals were inadequate. Findings showed there was statistically significant difference in volume of Commuters that board private vehicles to those that use UMTBs. The result was obvious because majority of sampled respondents' choice of transport mode was boarding of private vehicle that illegally operates as Passenger Service Vehicle. At the same time, the factors that influence Commuters' preference for choice of transport mode were different.

\section{Conclusion}

Findings revealed that UMTB system in the study area was very inadequate as measured from the Bus terminals, Bus stops and its functionality as perceived by the Commuters and licensed Operators. As a result of this, many Commuters would prefer to board unknown private cars to UMTB. The UMTB system is an important tool for 
promoting socio-economic development of a society. Thus, the UMTB Operators in the study area are therefore challenged to remain relevant to urban mobility through improved service delivery frameworks. The study recommends provision of adequate Bus stops, Terminals and ensure Operational coherency within the study areas.

\section{References}

[1] Adah, P. D. (2014). Appraisal of Abuja Metropolitan Management Council Structure and Process. MSc. Thesis, Ahmadu Bello University, Zaria.

[2] Akindele, O. A., Ogunleye, J. S., \& Muili, A. B. (2014). Intra Urban Pattern and Acceptability of Bus Station in Ilorin, Nigeria. Global Journal of Arts, Humanities and Social Sciences. 2, (8), 65-79.

[3] Ali, A. N. (2014). Assessment of Passenger Satisfaction with Intra-City Public Bus Transport Services in Abuja, Nigeria. Journal of Public Transportation, 17(1), 99-119.

[4] Bobai, F. D. and Fawohunre, F. A. (2014b). Road Infrastructure Development in Nigeria: Impact on Selected Corridors in Abuja Metropolis. Journal of Logistics and Transport, 6(1), 121-140.

[5] Ndikom, O. B. C. (2008). Elements of Transport Management. Lagos: Bunmico Publishers.

[6] Nwachukwu, A. A. (2014). Assessment of Passenger Satisfaction with Intra-City Public Bus Transport Services in Abuja, Nigeria. Journal of Public Transportation, 17(1), 99-119.

[7] Nwankwo, C. O., Fawohunre, F. A. \& Obasanjo O. T. (2016). Abuja Urban Mass Transit Company Operations Impact on Passengers' Movement within Abuja Metropolis. European Journal of Research in Social Sciences 4(6), 31-41.

[8] Nwaogbe, O. R., Ukaegbu, S.I. \& Ibe, C. C. (2013). The Quality of Mass Transit Service in Abuja, Nigeria: An Analysis of Customers Opinions. International Journal of Scientific and Technology Research, 2(12), 1-12.

[9] Ogwude, I. C. (2016). Managing Transport Infrastructure in Nigeria Cities. FUTA Journal of Management and Technology, (maiden edition), 17-28. Doi: 1.1/fjmt.2016/v1n1p2

[10] Okamura, T., Kaneko, Y., Nakamura, F., Wang, R., \& Regidor, J. R. F. (2011). Attitudes of Jeepney Passengers in Metro Manila, Considering Different Lifestyles. Proceedings of 11th International Congress of Asian Schools Association.

[11] Oluwole, M. S. \& Ojekunle, J. A. (2016). GIS Application for Determining Public Transport Access Level in the Federal Capital Territory (FCT), Abuja- Nigeria. Journal of Geography and Regional Planning, 9(8), 154-163. DOI: 10.5897/JGRP2016.0552

[12] Rodrigue, J-P. (2017). The Geography of Transport Systems, (4th ed.). New York: Routledge. Retrieved from https://people.hofstra.edu/geotrans/eng/methods/ch5m1en.html

[13] Salisu, G. (2014). Road Transportation Problems in Metropolitan Kano. Journal of Logistics and Transport, 6(1), 37-42.

[14] Ubogu, A. E. (2011). The Potentials of Rail-Road Integration for Port-Hinterland Freight Transport in Nigeria. International Journal for Traffic and Transport Engineering, 1(2), 89 107. 